\title{
Social Criticism in Karawitan Gadhon Lyrics Gatra Mutiara Jawa by Dedek Wahyudi (Stylistics Study)
}

\author{
Edysa Ariviani ${ }^{1}$, Sumarlam ${ }^{2}$, and Prasetyo Adi Wisnu Wibowo ${ }^{3}$ \\ \{1edysaa.1dp8@gmail.com, sumarlamwd.gmail.com, prasetyoadiwisnuwibowo@yahoo.co.id\} \\ ${ }^{1}$ Study Program of Descriptive Linguistic, Postgraduate, Sebelas Maret University, \\ ${ }^{2,3}$ Study Program of Javanese Literature, Faculty of Science and Culture, Sebelas Maret University
}

\begin{abstract}
The term "karawitan" refers to gamelan art that is widely used by Javanese people. Karawitan is one form of art combined with Sekar and Gendhing. Karawitan does not only feature one of the two, but both of these karawitan are performed together in order to produce beautiful musical instruments, one of them is Gadhon Gatra Mutiara Gatra, which emphasizes the beautiful aspects of instruments and vocals. Moreover the lyrics in it are used to convey messages to the audience. This is evidenced by the beauty of the use of lyrics that are used to convey moral messages and social criticism, especially for Javanese people with a background who like smooth and polite words in giving a message or criticism. The lyrics of Karawitan Gadhon Gatra Mutiara Jawa utilize the use of asonance, alliteration, and expression of social criticism so that this research is reviewed from a stylistic study by focusing on the specificity and beauty of the pronunciation style of an artist Dedek Wahyudi in one of his works in the form of Javanese gendhing combined with western music. This research uses a descriptive qualitative approach. Primary data sources are in the form of lyrics from Karawitan Gadhon Gatra Mutiara Jawa and interviewees. Secondary data sources refer to several studies and supporting books relating to the Javanese lexicon. Thus, in studying and interpreting the use of the language used in the lyrics of Karawitan Gadhon Gatra Mutiara Jawa this study uses stylistic theory. The results showed that the use of language in the lyrics of Karawitan Gadhon Gatra Mutiara Jawa is appropriate to be a means of expressing social criticism for Javanese people.
\end{abstract}

Keywords: Stylistics, Lirik Karawitan Gadhon Gatra Mutiara Jawa, Karawitan

\section{Introduction}

Karawitan Gadhon is a working of karawitan which only uses certain instruments including trigon, gender, kendhang, and demung accompanied by singer. Karawitan Gadhon is worked out in accordance with existing standards and notations. Dedek Wahyudi tried to work on Karawitan Gadhon with different creativity. He created the work with additional instruments including keyboard, saxophone, and bass. He did this so that Karawitan Gadhon 
had new innovations that followed the times but did not change the existing standard and made it easier for the audience to accept the message contained in the work. The lyrics have 10 stanzas, including Pola Sindhenan, Ladrang Wilujeng, Jineman, Tayuban, Sindhenan Gadhung Mlathi, Krenteg, Pola Palaran, Suwe Ora Jamu, Gugur Gunung created as beautiful as possible to be accepted by the people who enjoy it . The lyrics contained in it almost entirely contain social criticism of an increasingly modern era, especially for Javanese people who prefer subtlety in speaking, Dedek Wahyudi tries to make lyrics by using asonance and alliteration to produce the beauty of sound. This work is also one of the works used by Dedek Wahyudi to express his concern for generations who have begun to leave traditional art. The life of traditional music that is experiencing shocks due to changing times, but still able to survive the onslaught. Each of the lyrics has a meaning and meaning that clearly illustrates the current situation. Dedek Wahyudi tried to invite young people to keep the traditional arts that are starting to disappear in the age and foreign culture that comes.

Based on this background, the song lyrics in Karawitan Gadhon Gatra Mutiara Jawa can be studied with a stylistic review, because are found asonance, alteration and use of sentences by expressing the social criticism contained in the lyrics.

\section{Research Method}

This research method uses descriptive qualitative method with hermeneutic thinking strategy in the perspective of holistic criticism. Research is appreciated in the stylistic review of the lyrics of the song Karawitan Gadhon Gatra Mutiara Jawa by Dedek Wahyudi by asking for holistic criticism. The data consists of complaints of the sounds of language in songs and the author's sociohistorical background. The data source is library and author. Data collection is carried out through listening and note taking, library, interview. Data validation is done by triangulation techniques. The data analysis is carried out interactively with the following steps: (1) data reduction, (2) data presentation, and (3) conclusion consideration. Furthermore, the revelation of the meaning of the song lyrics of the Karawitan Gadhon Gadhon Gatra Mutiara Jawa was carried out with heuristic and hermeneutic readings.

\section{Results And Discussion}

Analysis of the use of asonance patterns (purwakanthi guru swara) or looping sound, alliteration (purwakanthi guru sastra) or looping consonants as follows.

\subsection{Asonance (Purwakanthi Guru Swara)}

Analysis of the use of asonance patterns (purwakanthi guru swara) in general, is meant to produce the effect of speech intelligibility, voice cracking, and the beauty of language (Subroto, 2013).

\subsubsection{Purwakanthi Guru Swara /o/}

Minangka sarana amangun, nus $\underline{a}$ 'As a means to build both country and bungs $\underline{a}(l w / 6)$ nation' 


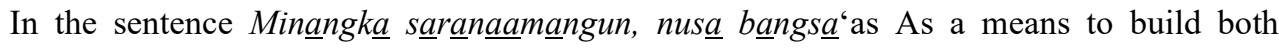
country and nation ', the pattern of asonance / a / in the word minangka' as', means of 'means', nusa' nusa ', nation' nation 'found in the first syllable of the back (ultima) in an open position and used vowel sounds / a / become / 0 /. The asonance pattern in the word amangun 'build' is contained in the penultimate syllable (penultima) in a closed position and the penultimate syllable (antepenultima) in an open position. The asonance location has strong rhythmic pressure. This asonance functions to obtain the effect of emphasis or just the beauty of sound.

\subsubsection{Purwakanthi Guru Swara /a/}

Asung gadhon kang rinonce, man eman eman eman (ps/2)

'bringing a series of gadhon, what a pity'

Sentence patterns Asung ga्adhon kang rinonce, man eman eman emann, the / a / asonance pattern in the asung word 'carry' is in the penultimate syllable (penultima) in an open position. The /a/ asonance pattern in the word gadhon 'gadhon' is found in the penultimate syllable (penultima) in a closed position. The / a / asonance pattern in the words kang 'yang' and eman 'unfortunate' is in the first syllable (ultima) in a closed position. The assonance provides rhythmic pressure, giving rise to the word's beauty.

\subsubsection{Purwakanthi Guru Swara /i/}

Jaman saikiki gamelan dha disakiti (lt/2) 'nowdays gamelan is being hurt by each other'

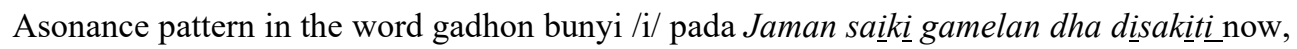
gamelan is hurt each other ', the asonance pattern / i / in the word saiki' now 'and the word hurt' hurt 'is found in the first syllable (ultima) in an open position and the penultimate syllable (penultima) in a closed position. The asonance pattern / $\mathrm{i} /$ gives emphasis so that the sound becomes more melodious

\subsubsection{Purwakanthi Guru Swara /u/}

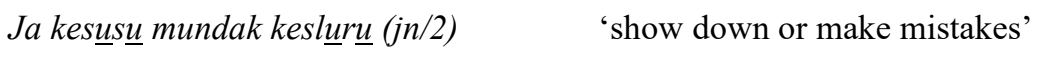

Asonance pattern /u/ pada ja kesusu mundhak kesluru 'show down or make mistakes', the asonance pattern / $\mathrm{u} /$ is in the first syllable syllable from the back (ultima) in the open position and the penultimate syllable (penultima) in the closed position. The $/ \mathrm{u} /$ asonance pattern in the sentence has sound cohesiveness, so speech is more beautifuly used.

\subsubsection{Purwakanthi Guru Swara lêl}

$$
\text { .../kekehing pakemira (lw/11) 'according to the rules' }
$$

Asonance /e/ in the sentence contained in the penultimate syllable (penultima) and also in the penultimate syllable (antepenultima)are in a closed position. The asonance pattern in the data above contains the impression of tenderness so that the language becomes tunable

\subsubsection{Purwakanthi Guru Sastra /g/}

$$
\begin{aligned}
& \text {... } / \text { gugur gunung tandang gawe 'Working together to carry out the task' } \\
& (\mathrm{gg} / 2)
\end{aligned}
$$


Fragments of the fall sentence of the tandang gawe gugur gunung 'working together to carry out the task', the alliteration pattern / $\mathrm{g} /$ is found in the penultimate syllable (penultima) in an open position. Alliteration patterns in the data above have a strong element of language keritmisan.

\subsubsection{Purwakanthi Guru Sastra /h/}

\section{Gumregah gumregah yo bareng jumangkah 'Get up and go together'} $(l w / 13)$

Setence gumregah gumregah yo bareng jumangkah 'get up and go together, step ', the alliteration pattern / $\mathrm{h} /$ in the calomat is found in the first syllable of the back (ultima) in an open position. The / $\mathrm{h} /$ alitersi pattern in the above data gives a strong emphasis so that the function is clearly visible

\subsubsection{Purwakanthi Basa/Lumaksita}

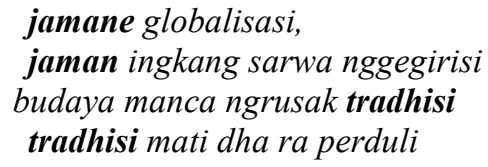

\author{
'globalization era' \\ 'which is to frightening \\ 'foreign cultures threaten the tradition' \\ 'no one cares for the dead tradition'
}

Purwakanthi basa/lumaksita on karawitan lyrics is a taxation based on synonyms, final syllables with successive initial syllables jaman 'era' or the equation of the last letter with consecutive initial letters in a row with the next line tradhisi 'tradition'. At least there are several equivalent terms in the form of the term purwakanthi basa is purwakanthi lumaksita, purwakanthi lumaksana, in Indonesia called 'sajak berkait' and repetisi anadiplosis.

\subsection{Utilization of Word Forms and Vocabulary Selection (Dictation) as Author's Style of Disclosure}

Dedek Wahyudi expressed his complaints and concerns in the midst of this globalization era, which greatly affected the social conditions of the community, especially in the traditional arts scene that he was involved in. He said that the current situation was in an emergency or dangerous situation. If not responded with caution, the traditional arts can be displaced and marginalized by other arts both from within their own country and art from abroad. The world has changed, therefore, if traditional arts are not responded to properly they will be destroyed and need to use methods so that how traditions can continue to exist in an increasingly cruel era. Dedek Wahyudi must work hard to maintain traditions in this era of globalization. He gave a message that besides traditional arts must be preserved, traditional arts must also be developed. Changes in traditional arts are influenced by the social conditions of the people. In the past, traditional arts were highly considered by the public and were well-positioned. People in ancient times admired traditional art and were not interested in foreign art.

However, because of the social conditions of today's society that has changed drastically, making the traditional arts began to be ignored by the community and chose to know more about foreign art. Even now the people don't know their art anymore which they should preserve and preserve. That is very unfortunate by Dedek Wahyudi so he tries to open the eyes of the whole community through his work that traditional art is appropriate and must be maintained at all times. Dedek Wahyudi's way to overcome the extinction of traditional arts is to create a work that he worked on from the beginning of his career to the present which still 
uses the value of tradition in it but still follows the times. Dedek Wahyudi said that there were many kinds of works he created. There is a form of music concerts, dance music, theater music, film music, puppet music, and there are several kinds of works that he does is a repetition of syllables or words (free morpheme) in one array, inter-array, and between a song. The syllabic iteration distribution is at the beginning, in the middle, and at the end of the word. Furthermore, repetition of words or parts of words has the potential for entire vocabulary. Talking about the vocal work, that the lyrics worked on Karawitan Gadhon Gatra Mutiara Jawa are all made by Dedek Wahyudi himself, but he still uses big ideas in one work. The big idea used by Dedek Wahyudi is one of the poems in the Kalatidha fiber. Nearly every work in Dedek Wahyudi uses the seventh poem as follows:

Amenangi jaman edan /Ewuhaya ing pambudi/ Melu edan nora tahan / Yen tan melu anglakoni/ Boya keduman melik/ Kaliren wekasanipun/ Ndilalah karsa Allah / Begja begjane kang lali/Luwih Begja kang eling klawan waspada//( Serat Kalatidha pupuh 7)

'Facing crazy time/ things have become difficult/ also crazy enough can't stand it/ if not participate do/ didn't get a part/ finally suffering from hunger/ it is God's will/ how happy people who forget/ happier those who are aware and alert//

\subsection{Use of critical sentences in Song Lyrics Karawitan Gadhon Gatra Mutiara Jawa}

Every lyric contained in Gadhon Gatra Mutiara Jawa almost contains criticism. This is intentionally done by the author so that the public realizes that actually Javanese art is appropriate and must be maintained. The criticism is not only highlighted in anger but is shown through humorous insinuations created by the author so that it can be easily understood by connoisseurs without any emotional sense in capturing it. In the lyrics as follows

Sruning cipta, raden Asung gadhon kang rinonce,

man eman eman eman 'Beginning of creation, Raden (nickname for boys)' 'Bring the gadhon series'

Murih bisa, gones wicarane 'Hopefully, sweet way of speaking'

Murih bisa gadhon anjayeng bawana (PS) 'Hopefully Gadhon can flourish in the world'

The lyrics of the Javanese Pearl Gatra in the sindhenan pattern above indicate an initial purpose of creation. The series of Karawitan Gadhon created by the author is expected to be witnessed by all people on earth and can continue to grow in the archipelago. The lyrics above are very clear and firm enough for a beginning in a work. The author has given clear instructions as to what is the problem in the Republic of Indonesia. Karawitan Gadhon Gatra Mutiara Java contained criticism between humans and God. The author also creates lyrics that build for the community as follows:
Sabar sareh, darana becike
puja puji,, gusti midhangetke
Mung durung wancine
mung durung wektune
'Patience calm is better'
'May God listen'
'It's just not yet'
'It's just not time yet'

Titi lan mangsane bakal katekan sedyane, raden 'The time and time will come when he wants.' Raden (the name for a respected man)

pasrah gusti pangerane

'Surrender to the Almighty God'

Kae rembulane wus katon angawe-awe sumamburat mancorong katon cahyane muga padhang kahanane (SGA)

'That month is already seen waving' 'Radiating and shining the light looks' 'May the situation brighten' 
Based on the lyrics above, it can be seen that reminding humans of whatever problems they face, humans are asked to submit to God. It was explained that if humans are calm and patient then time will answer. Humans are asked to continue praying to God, because God will surely listen to all the complaints of His people. One of the lyrics also illustrates the excitement because not all young people today forget the traditional arts. There are still some young people who still have a sense of responsibility to maintain and develop traditional arts. If humans do not remember God, then humans will be influenced by foreign cultures and do things that are inappropriate.

Jamane globalisasi
jaman ingkang sarwa nggegirisi
Budaya manca ngrusak tradisi
Tradisi mati dha ra perduli
Dirusak dening acara televise sing
Nggegilani
we lha dalah, gendheng puniki(PP)

'globalization era'

'which is to frightening'

'foreign culture threaten tradition'

No one cares for the dead tradition'

'Damaged by educated TV programs'

'oh my gosh, what a crazy world'

The lyrics section above is considered as the main part by the author. Because in the lyrics it covers the most prominent criticisms made by the author to criticize the current situation which is very cruel to get rid of traditional art. The era of globalization which is very evil because it can affect the soul of the nation which is described in the lyrics above in the second line which reads the era of the Sarwa Uncleaning 'era that is too scary'.

\section{Conclusion}

The unique aspect of the beauty of language in the lyrics of the Javanese Pearl Gadhon music is a valuable literary work. The use of swara, literature and lumaksita purwakanthi functions to create sound cohesiveness, emphasize meaning, and show integration between lines. The choice of word forms and the use of aesthetic and concrete vocabulary to convey criticism that contains social messages to love one's own culture through each song lyrics with language that is able to present the appeal of the audience. This is an attempt by the author to realize his expressivity / linguistic style of the author through the lyrics of the song Karawitan Gadhon Gatra Mutiara Jawa.

\section{References}

[1] Abrams, M.H., A Glossary of Literary Terms. New York: Holt, Rinehart and Wiston, 1981.

[2] Al-Ma'ruf, Ali Imron., "Dimensi Sufistik dalam Stilistika Puisi 'Tuhan, Kita Begitu Dekat' Karya Abdulhadi W.M.," Tsaqafa, Jurnal Kajian Seni dan Budaya Islam, vol.1, pp. 101-118, 2012.

[3] Aminuddin, M., Stilistika Pengantar Memahami Bahasa dalam Karya Sastra. Semarang: IKIP Semarang Press, 1995.

[4] Faris, Salman., "Islam dan Budaya Lokal (Studi Atas Tradisi Keislaman Masyarakat Jawa)," Thaqafiyyat, vol. 15. pp.74-90, 2014.

[5] Hilal, Ahmad., Laraib, Bushra., Mustafa, Maria., Iqbal, Saadia,. \& Kundi, Muhammad Iqbal., "Stylistic Analysis of The Voice'," International Journal of Linguistics, vol. 4, pp. 433-442, 2012.

[6] Nurgiyantoro, Burhan., "Stile dan Stilistika", Diksi, vol. 1, pp. 1-9, 1993 [7] Nurgiyantoro, Burhan. 2005. Teori Pengkajian Fiksi. Yogyakarta : GMUP. 
[8] Nurgiyantoro, Burhan. 2005. Teori Pengkajian Fiksi. Yogyakarta : GMUP.

[9] Nurgiyantoro, Burhan., "Stile dan Stilistika", Diksi, vol. 1, pp. 1-9, 1993.

[10] Nurhayati, Siti. 2013. "Pemanfaatan Potensi Bahasa Jawa dalamLirik Lagu Dolanan Tradisional Jawa Karya Ki Narto Sabdo. (skripsi).” Surakarta: Fakultas Sastra dan Seni Rupa Universitas Sebelas Maret.

[11] Padmoesoekotjo, S. Ngengrengan Kasusastran Djawa I \& II. Djokdja: Hien Hoo Sing, 1955.

[12] Subroto, D. Edi., "Kajian Stilistika Teks Bahasa Pedalangan Wayang Purwa Gaya Surakarta," Jurnal Bahasa dan Seni, vol. 41, pp. 143-158, 2013.

[13] Sudaryanto., Metode dan Aneka Teknik Analisis Bahasa Pengantar Penelitian Wahana Kebudayaan secara Linguistis. Yogyakarta: SERI ILDEP, 1993.

[14] Sudjiman, P. Bunga Rampai Silistika. Jakarta: Pustaka Utama Grafiti, 1993.

[15] Verhaar, J.W.M. Asas-asas Linguistik Umum (Cetakan Kesembilan). Yogyakarta: Gadjah Mada Press, 2016.

[16] Wibowo, M.A.K., Satoto, Soediro, \& Sumarlam., "Pemanfaatan Bunyi Bahasa dalam Serat Wulang Reh Karya Pakubuwana IV (Kajian Stilistika)," Thaqafiyyat, vol. 18, pp. 19-48, 2017.

[17] Yaziad. "Larangan Bersikap Ghuluw," [Online]. Available: https://almanhaj.or.id/12664larangan-bersikap-ghuluw-2.html. 